\title{
UF/IFAS Standardized Nutrient Recommendations for Vegetable Crop Production in Florida ${ }^{1}$
}

\author{
Rao Mylavarapu, George Hochmuth, and Guodong Liu²
}

\section{Introduction}

This publication presents the fertilization recommendations for vegetable crops based on soil tests performed by the UF/IFAS Extension Soil Testing Laboratory (ESTL). It contains the basic information from which ESTL soil test reports and fertilization recommendations are generated. UF/IFAS Standardized Nutrient Recommendations for Agronomic Crops can be found in SL129 (https://edis.ifas. ufl.edu/ss163) (Mylavarapu, Wright, and Kidder 2021). The audiences for this information include commercial and small farmers, crop advisers and consultants, state and local agencies, fertilizer industry, and any interested individuals interested in sustainable nutrient and environmental management.

\section{Soil Testing}

Soil testing is a scientific tool for effective nutrient management that provides an estimate or an index of the available nutrient-supplying capacity of the soil. This index can then be used to develop recommendations for nutrient applications based on plant needs and the contribution of nutrients already in the soil to the crop nutrient requirement during the growing season. This best management practice (BMP) helps farmers achieve profitable crop yields while protecting the environment from excessive fertilization and nutrient losses. In successful soil testing, (1) soil samples that adequately represent the field or management unit are sent to the lab; (2) the laboratory uses calibrated soil test methods for predicting fertility requirements; and (3) the fertilizer recommendations made are based on measured crop responses.

The ESTL extracts phosphorus $(\mathrm{P})$, potassium $(\mathrm{K}), \mathrm{Mg}$, $\mathrm{Ca}$, copper $(\mathrm{Cu})$, manganese $(\mathrm{Mn})$, and zinc $(\mathrm{Zn})$ from soil samples with the Mehlich-3 extractant and bases fertilizer recommendations for those nutrients on the test results and interpretation. The use of the Mehlich-3 extractant enhances the extraction of micronutrients and allows for a broader range of applicability (low to high soil $\mathrm{pH}$ ranges) when compared to the Mehlich-1 extractant. Other advantages of the Mehlich-3 extractant include improved extraction of $\mathrm{P}$ in soils with high iron and aluminum (Al) accumulations by facilitating the dissociation of $\mathrm{P}$ from these compounds through the addition of fluoride, as well as the extraction of exchangeable cations by the addition of ammonium nitrate. Additional information on M-3 extractant, ingredients, correlation and advantages can be found in SL407 (https://edis.ifas.ufl.edu/publication/SS620) (Mylavarapu et al. 2020).

Nitrogen (N) fertilization is not based on soil tests but on crop need documented in research literature. Liming recommendations are based on the Adams-Evans lime requirement test (a calibration equation developed for Florida soils) and the target $\mathrm{pH}$ for the crop for which the recommendation is being made.

1. This document is CIR1152, one of a series of the Horticultural Sciences Department, UF/IFAS Extension. Original publication date March 2000. Revised December 2021. Visit the EDIS website at https://edis.ifas.ufl.edu for the currently supported version of this publication.

2. Rao Mylavarapu, professor, Department of Soil and Water Sciences; George Hochmuth, professor emeritus, Department of Soil and Water Sciences; and Guodong Liu, assistant professor, Horticultural Sciences Department; UF/IFAS Extension, Gainesville, FL 32611. 


\section{Soil Sampling}

Soil testing depends on soil samples that are representative of the soil for the field in question. Samples should be collected from a relevant depth at specific locations to obtain a total number of samples that represent the conditions of the field.

Samples should be collected from the top six inches of the soil, because this is the part of the soil that is typically tilled and contains many of the nutrient-absorbing roots. The number of samples taken depends on the number of management units within the field. Management units are areas that will receive different agricultural practices (different crops or different planting dates) or have different soil types. These differences potentially contribute to different fertilization needs and management approaches. Once management units have been determined based on variability in the field, each management unit should be sampled separately. Samples should be collected from each management unit using a random approach to sample location selection in order to obtain a total of 20 samples. Each sample should be collected with a soil sampling probe and retained in a plastic bucket to composite all of the samples. Once sampling of the management unit is complete and the soils in the bucket are thoroughly mixed together, a sample volume of about one-half pint is obtained from the bucket and placed in the paper bag provided for soil-testing submissions to the lab. Additional information on management units and soil sampling schemes can be found in the EDIS document SL190, "UF/IFAS Nutrient Management Series: Soil Sampling Strategies for Precision Agriculture" (https://edis.ifas.ufl.edu/ss402) (Mylavarapu and Lee 2014).

\section{Water Management}

Nutrients can leach in Florida's sandy soils due to heavy rainfall or excessive irrigation. The fertilization recommendations presented in this circular were developed from research and on-farm experience with optimum water management. Irrigation requirements are primarily determined by crop water requirements, the characteristics of the irrigation system, management practices, and the physical and certain chemical characteristics of the soil in the irrigated area. Irrigation water quality criteria should also be considered in relation to fertilization, including salinity of the irrigation water, sodium adsorption ratio (i.e., the ratio of sodium to calcium [Ca] and magnesium [Mg] [Reeve et al. 1954; Oster and Sposito 1988]), pH, alkalinity, organic contaminates, and heavy metals. A wellmanaged irrigation program will use water that does not curtail the effects of fertilization and will keep water and nutrients in the root zone, where both inputs will benefit yield and vegetable quality while minimizing chances for negative environmental impact. For more information on water management, see AE260, "Principles and Practices of Irrigation Management for Vegetables" (https://edis.ifas.ufl. edu/cv107).

\section{Managing Soil pH}

In the southeastern United States, most native mineral soils are naturally acidic and require management for increasing $\mathrm{pH}$ (via liming) and nutrients to maintain optimal soil fertility. Liming reduces soil acidity, thereby changing numerous soil parameters related to fertilization in order to improve the yield or quality of a crop. Additionally, many of the soils found in Florida have historically been managed extensively for $\mathrm{pH}$ and may not require immediate additional liming. However, there are regions in south Florida that have calcareous soils with as much as $90 \%$ free calcium carbonate on the soil surface, thereby limiting nutrient availability. In these soils, liming should be absolutely avoided and appropriate methods to lower the $\mathrm{pH}$ should be considered and implemented instead. Other factors that can affect soil $\mathrm{pH}$, including the soils, crops produced, ecosystem, local BMPs implemented, and economics should be understood before soils are managed for $\mathrm{pH}$.

While calibrated lime requirement tests are part of standard soil tests in this region, the affordability and availability of agricultural lime and amendments has led to a tendency to over-lime soils. Soil pH should not be lowered unless there is evidence that plant growth is being adversely affected by $\mathrm{pH}$. When lime is applied, adequate time for the liming material to react with the soil and raise $\mathrm{pH}$ should be allowed before additional management actions are taken. If liming is required, the level of dissolved calcium carbonate in irrigation water drawn from groundwater should be considered when determining lime application rates.

Benefits of liming with dolomitic limestone, when necessary, include reduction of $\mathrm{Al}$ toxicity in mineral soils, additional $\mathrm{Mg}$ and $\mathrm{Ca}$ as nutrients, and increased availability of other nutrients such as P. Conversely, overliming can cause low-P stress, Mn deficiency, other micronutrient deficiencies, and plant physiological disorders. In areas with naturally occurring carbonates that contribute to high soil $\mathrm{pH}$, application of elemental sulfur (or ammonium sulfate when soil $\mathrm{pH}$ is lower than 7.25) and micronutrients in a band is recommended in order to most practically avoid the adverse effects of high $\mathrm{pH}$. Application of a nitrogen fertilizer that provides sufficient hydronium ions in the root zone during chemical or biological reactions in soil 
will lower $\mathrm{pH}$ gradually with long-term use. In some cases, when the cause of high soil $\mathrm{pH}$ is natural, there may not be a cost-effective mechanism for lowering the $\mathrm{pH}$ and crops with a tolerance for higher $\mathrm{pH}$ ranges should be grown. For more information on $\mathrm{pH}$ management, see EDIS documents "Liming of Agronomic Crops" (SS-AGR-153) (https://edis.ifas.ufl.edu/aa128), "Lowering Soil pH to Optimize Nutrient Management and Crop Production" (SL437) (https://edis.ifas.ufl.edu/ss651), and "Agricultural Soils of Florida” (SL441) (https://edis.ifas.ufl.edu/ss655).

\section{Major Fertilization Factors}

Depending on the crop and soils, natural fertility may not provide adequate levels of all required nutrients for desired plant growth. Fertilizers are used to provide additional nutrients in order to achieve economical crop production. In order to attain adequate nutrients for crop production while minimizing the risk of loss of nutrients to the environment, attention must be given to the four major soil fertilization factors: right source, right rate, right placement, and right timing. These factors, known as the 4 Rs, should be evaluated when reviewing soil testing results to develop a personalized, integrated approach to nutrient management that makes efficient use of fertilizer investment for crop production and for environmental protection. The rate of fertilizer is a part of the overall nutrient management program. The recommended rates have been determined to provide adequate nutrient amounts even under highest yield potentials. Rate recommendations may change depending on new research. The 4 Rs are fully interdependent and linked in the cropping system-they must each be considered and work together in order to sustain the economy, society, and the environment. Considerations for selecting the right source may include the ease of application of a nutrient, the cost per unit of the nutrient, and the efficiency of the nutrient. Practicing the right rate of nutrient application is intrinsically linked to soil testing. Soil testing can determine the amount of fertilizer needed for the crop production that meets plant requirements and protects against nutrient losses. The right timing of nutrients takes into consideration the growth pattern of the specific crop and changes in nutrient demand during the growing season in order to meet the needs of growth while also minimizing the chance of leaching of nutrients. The right placement of nutrients involves determining where the plant will have the best access to the nutrients-primarily in the root zone or just ahead of the advancing root system - and using a nutrient placement approach (such as banding and broadcasting) to meet those needs. The right placement should also consider the nutrient being applied. For example, $\mathrm{P}$ can become unavailable in some soils when broadcast-applied and can accumulate over time in unavailable forms, and ammoniacal $\mathrm{N}$ can significantly volatilize when left on the surface of a soil with a pH higher than 7.3. Examples of how the 4 Rs influence fertilization include consideration of controlled release or organic fertilizers (right source), using soil testing results to determine the amount of fertilizer needed (right rate), application by banding or broadcasting depending on the type of crop and the development or spread of the root system (right placement), and anticipating changes in plant-specific growth and nutrient demand so that application can be timed to meet the needs of growth (right timing). For more information on the 4Rs, please refer to the EDIS document “The Four Rs of Fertilizer Management" (SL411) (https:// edis.ifas.ufl.edu/ss624).

\section{Soil Test Rating Level}

The current UF/IFAS interpretation of the Mehlich-3 extractant is presented in Table 1 . This soil test has been extensively researched to correlate the soil text index (the concentration of nutrients extracted from the soil sample) with crop yield. This index tells us the relative level of a nutrient that will likely contribute to the crop nutrient requirement during the growing season. The response curve of these data are used to partition the range of soil text index results into corresponding low, medium, and high indexes. Through the process of calibration, crop nutrient requirements are determined for soil test values that fall within the indexes. This interpretation scale has been verified by field research on growers' fields throughout Florida for vegetable production.

Interpretations of results for Mehlich-3 extractable micronutrients have been developed from experience and field testing with vegetables (Table 2). Because responses to micronutrients are commodity-specific, these interpretations should be used as guides only. Zinc, $\mathrm{Cu}$, and $\mathrm{Mn}$ can build up with time since they are quite immobile in the soil. The decision to add micronutrients should include an accounting for all sources, such as fungicides and micronutrient content in irrigation water.

\section{Soil Test Recommendations}

Soil test reports from the ESTL are computer-generated from soil test data and crop information. Reports contain the results of the tests (soil $\mathrm{pH}$ and ppm extractable $\mathrm{P}, \mathrm{K}$, $\mathrm{Mg}, \mathrm{Ca}$, and $\mathrm{Cu}, \mathrm{Mn}$, and $\mathrm{Zn}$, if requested), a rating of the P, K., and Mg (high to low), and a fertilization recommendation. The recommendation is composed of two parts: (1) the rates of $\mathrm{N}, \mathrm{P}_{2} \mathrm{O}_{5}$, and $\mathrm{K}_{2} \mathrm{O}$ fertilizer to apply and (2) 
footnotes that give important information about fertilization management, such as application timing, special crop requirements, etc. Soil testing should be performed annually in most cases, with future sampling frequency based on several successive years of soil testing results.

Table 3 contains crop descriptions, target $\mathrm{pH}$, and $\mathrm{N}, \mathrm{P}_{2} \mathrm{O}_{5}$ and $\mathrm{K}_{2} \mathrm{O}$ recommendations for each of the three soil test rating levels, for which footnotes will be printed for each of the crop reports and the references upon which the recommendations are based.

Recommended fertilizer rates have been determined from research using typical standard bed spacing (Table 5). These fertilizer rates are expressed on a "per acre" basis, which can be converted to pounds per 100 linear bed feet. For planting patterns other than the typical bed spacing, refer to Table 6 for the equivalent fertilizer application rate given in pounds of nutrient per 100 linear bed feet. Using Table 5 and Table 6 will ensure correct fertilizer application rate using variable planting patterns. For more information on the linear bed foot system, please see SL409 (https://edis.ifas.ufl.edu/ ss622).

\section{References}

Dukes, M. D., L. Zotarelli, G. D. Liu, and E. H. Somonne. 2021. Principles and Practices of Irrigation Management for Vegetables. AE260. Gainesville: University of Florida Institute of Food and Agricultural Sciences. https://edis.ifas. ufl.edu/ae260

Hochmuth, G., and E. Hanlon. 2020a . A Summary of $N, P$, and K Research with Eggplant in Florida. CV228. Gainesville: University of Florida Institute of Food and Agricultural Sciences. https://edis.ifas.ufl.edu/cv228

Hochmuth, G., and E. Hanlon. 2020b. A Summary of N, P, and K Research with Pepper in Florida. CV230. Gainesville: University of Florida Institute of Food and Agricultural Sciences. https://edis.ifas.ufl.edu/cv230

Hochmuth, G., and E. Hanlon. 2020c . A Summary of $N$, $P$, and K Research with Cucumber in Florida. CV226. Gainesville: University of Florida Institute of Food and Agricultural Sciences. https://edis.ifas.ufl.edu/cv226

Hochmuth, G., and E. Hanlon. 2020d. A Summary of N, P, and $K$ Research with Potato in Florida. CV233. Gainesville: University of Florida Institute of Food and Agricultural Sciences. https://edis.ifas.ufl.edu/cv233
Hochmuth, G., and E. Hanlon. 2020e. A Summary of $N, P$, and K Research with Snap Bean in Florida. CV234. Gainesville: University of Florida Institute of Food and Agricultural Sciences. https://edis.ifas.ufl.edu/cv234

Hochmuth, G., and E. Hanlon. 2020f. A Summary of N, $P$, and K Research with Sweet Corn in Florida. CV235. Gainesville: University of Florida Institute of Food and Agricultural Sciences. https://edis.ifas.ufl.edu/cv235

Hochmuth, G., and E. Hanlon. 2020g. A Summary of N, $P$, and K Research with Watermelon in Florida. CV232. Gainesville: University of Florida Institute of Food and Agricultural Sciences. https://edis.ifas.ufl.edu/cv232

Hochmuth, G., and E. Hanlon. 2020h. A Summary of N, P, and K Research with Tomato in Florida. CV236. Gainesville: University of Florida Institute of Food and Agricultural Sciences. https://edis.ifas.ufl.edu/cv236

Hochmuth, G. J., and E. A. Hanlon. 2018. Calculating Recommended Fertilizer Rates for Vegetables Grown in Raised-Bed, Mulched Cultural Systems. SS516. Gainesville: University of Florida Institute of Food and Agricultural Sciences. https://edis.ifas.ufl.edu/ss516

Hochmuth, G., R. Mylavarapu, and E. Hanlon. 2017a. Developing a Soil Test Extractant: The Correlation and Calibration Processes. SS622. Gainesville: University of Florida Institute of Food and Agricultural Sciences. https:// edis.ifas.ufl.edu/ss622

Hochmuth, G., R. Mylavarapu, and E. Hanlon. 2017b. Fertilizer Recommendation Philosophies. SS623. Gainesville: University of Florida Institute of Food and Agricultural Sciences. https://edis.ifas.ufl.edu/ss623

Hochmuth, G., R. Mylavarapu, and E. Hanlon. 2017c. Soil Testing for Plant-Available Nutrients - What Is It and Why Do We Use It? SS621. Gainesville: University of Florida Institute of Food and Agricultural Sciences. https://edis.ifas. ufl.edu/ss621

Hochmuth, G., R. Mylavarapu, and E. Hanlon. 2017d. The Four Rs of Fertilizer Management. SS624. Gainesville: University of Florida Institute of Food and Agricultural Sciences. https://edis.ifas.ufl.edu/ss624

Liu, G., K. Morgan, Y. Li, L. Zotarelli, J. DeValerio, and Q. Wang. 2019. What is 4R Nutrient Stewardship? HS1264. Gainesville: University of Florida Institute of Food and Agricultural Sciences. https://edis.ifas.ufl.edu/hs1264 
Mylavarapu, R., W. G. Harris, and G. Hochmuth. 2019. Agricultural Soils of Florida. SS655. Gainesville: University of Florida Institute of Food and Agricultural Sciences. https://edis.ifas.ufl.edu/ss655

Mylavarapu, R., G. Hochmuth, C. Mackowiak, A. Wright, and M. Silveira. 2019. Lowering Soil pH to Optimize Nutrient Management and Crop Production. SS651. Gainesville: University of Florida Institute of Food and Agricultural Sciences. https://edis.ifas.ufl.edu/ss651

Mylavarapu, R., T. Obreza, K. Morgan, G. Hochmuth, V. Nair, and A. Wright. 2020. Extraction of Soil Nutrients Using Mehlich-3 Reagent for Acid-Mineral Soils of Florida. SS620. Gainesville: University of Florida Institute of Food and Agricultural Sciences. https://edis.ifas.ufl.edu/ss620

Mylavarapu, R. S., J. F. Sanchez, J. H Nguyen, and J. M. Bartos. 2002. "Evaluation of Mehlich-1 and Mehlich-3 Extraction Procedures for Plant Nutrients in Acid Mineral Soils of Florida." Comm. Soil Sci. Plant Anal. 33 (5-6): 807-820. https://doi.org/10.1081/CSS-120003067

Mylavarapu, R., and D. L. Wonsuk. 2020. UF/IFAS Nutrient Management Series: Soil Sampling Strategies for Precision Agriculture. SS402. Gainesville: University of Florida Institute of Food and Agricultural Sciences. https://edis.ifas. ufl.edu/ss402

Mylavarapu, R., D. Wright, and G. Kidder. 2021. UF/IFAS Standardized Fertilization Recommendations for Agronomic Crops. SS163. Gainesville: University of Florida Institute of Food and Agricultural Sciences. https://edis.ifas.ufl.edu/ ss 163

Oster, J. D., and G. Sposito. 1980. “The Gapon Coefficient and the Exchangeable Sodium PercentageSodium Adsorption Ratio Relation." Soil Science Society of America Journal 44 (2): 258-260. https://doi.org/10.2136/ sssaj1980.03615995004400020011x

Reeve, R. C., C. A. Bower, R. H. Brooks, and F. B. Gschwend. 1954. "A Comparison of the Effects of Exchangeable Sodium and Potassium upon the Physical Condition of Soils." Soil Science Society of America Journal 18 (2): 130-132. https://doi.org/10.2136/ sssaj $1954.03615995001800020004 \mathrm{x}$

Wright, D. L., and C. Mackowiak. 2018. Liming of Agronomic Crops. AA128. Gainesville: University of Florida Institute of Food and Agricultural Sciences. https://edis.ifas. ufl.edu/aa128
Zotarelli, L., C. E. Barrett, A. Luiz, B. R. da Silva, C. T. Christensen and G. K. England. 2021. Nitrogen Fertilization Guidelines for Bare-Ground and Plastic Mulch Cabbage Production in Florida. HS1428. Gainesville: University of Florida, Institute of Food and Agricultural Sciences. https:// edis.ifas.ufl.edu/publication/HS1428

Zotarelli, L., T. Wade, G. K. England, and C. T. Christensen. 2021. Nitrogen Fertilization Guidelines for Potato Production in Florida. HS1429. Gainesville: University of Florida, Institute of Food and Agricultural Sciences. https:// edis.ifas.ufl.edu/publication/HS1429 
Table 1. Mehlich-3 soil test interpretations used for vegetable crops on mineral soils.

\begin{tabular}{|c|c|c|c|}
\hline \multirow{2}{*}{ Element } & Low & Medich-3, $\left.\mathbf{~ m g / k g ~} \mathbf{~}^{-1} \mathbf{~} \mathbf{p p m}\right)$ & High \\
\hline $\mathrm{P}$ & $\leq 25$ & $26-45$ & $>45$ \\
\hline $\mathrm{K}$ & $\leq 35$ & $36-60$ & $>60$ \\
\hline Mg & $\leq 20$ & $21-40$ & $>40$ \\
\hline Source: Mylavarapu et al. (2020) & & & \\
\hline
\end{tabular}

Table 2. Interpretations of Mehlich-3 soil test for micronutrients.

\begin{tabular}{|l|c|c|}
\hline \multicolumn{1}{|c|}{ Interpretations } & \multicolumn{2}{|c|}{ Soil pH (mineral soils only) } \\
\cline { 2 - 3 } & $\mathbf{5 . 5 - 5 . 9}$ & $\mathbf{6 . 0 - 6 . 4}$ \\
\hline Test level below which there may be a crop response to applied copper. & \multicolumn{1}{|c|}{ Test level (parts per million) } \\
\hline Test level above which copper toxicity may occur. & $0.7-1.0$ & $1.0-1.3$ \\
\hline Test level below which there may be a crop response to applied manganese. & $3.5-5.0$ & $5.0-8.0$ \\
\hline Test level below which there may be a crop response to applied zinc. & $10.3-12.7$ & $12.7-15.1$ \\
\hline From “Notes in Soil Science" No. 9 1983, and Mylavarapu et al. (2002). & 1.7 & $1.7-2.2$ \\
\hline
\end{tabular}




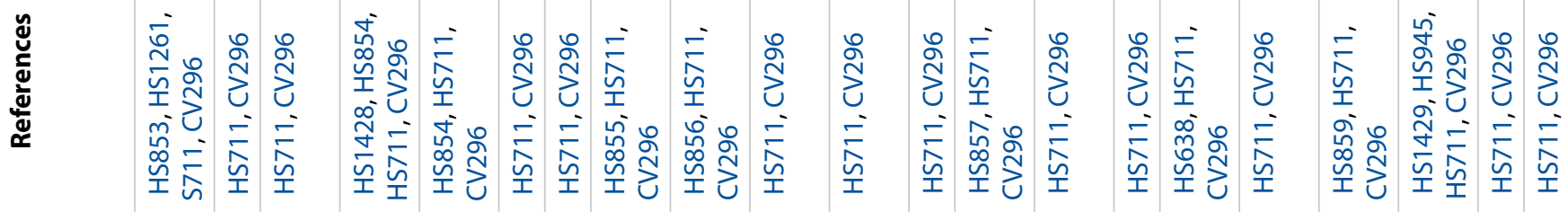

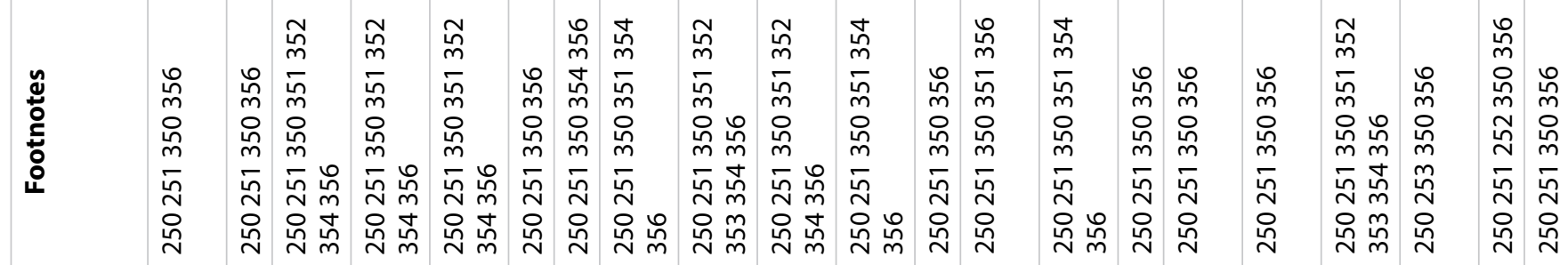

$\begin{array}{llllllllllllllllllllllll}\mathbf{I} & 0 & 0 & 0 & 0 & 0 & 0 & 0 & 0 & 0 & 0 & 0 & 0 & 0 & 0 & 0 & 0 & 0 & 0 & \stackrel{h}{h} & 0 & 0\end{array}$

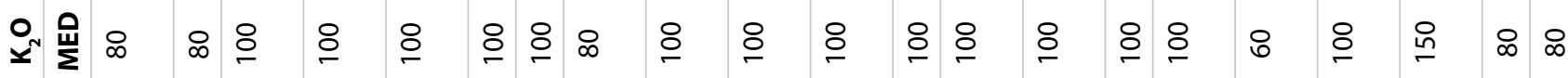

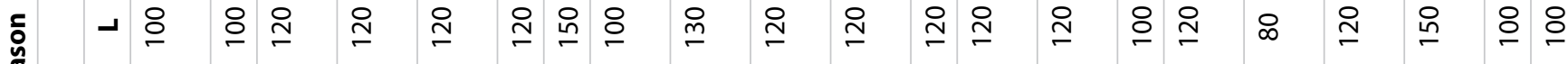

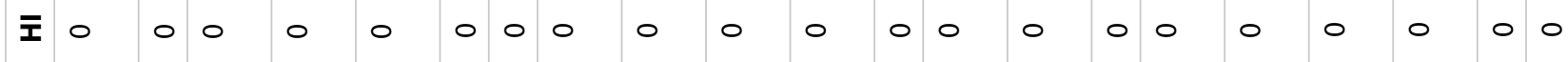

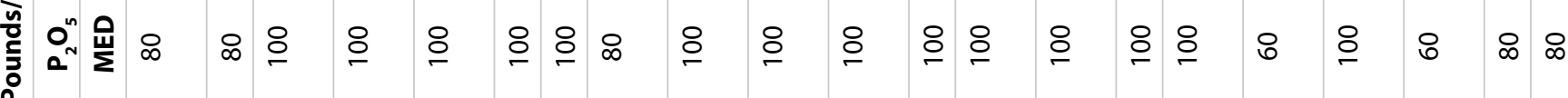

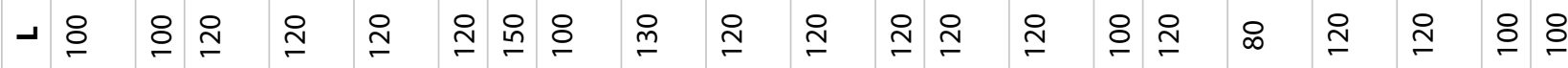

亲

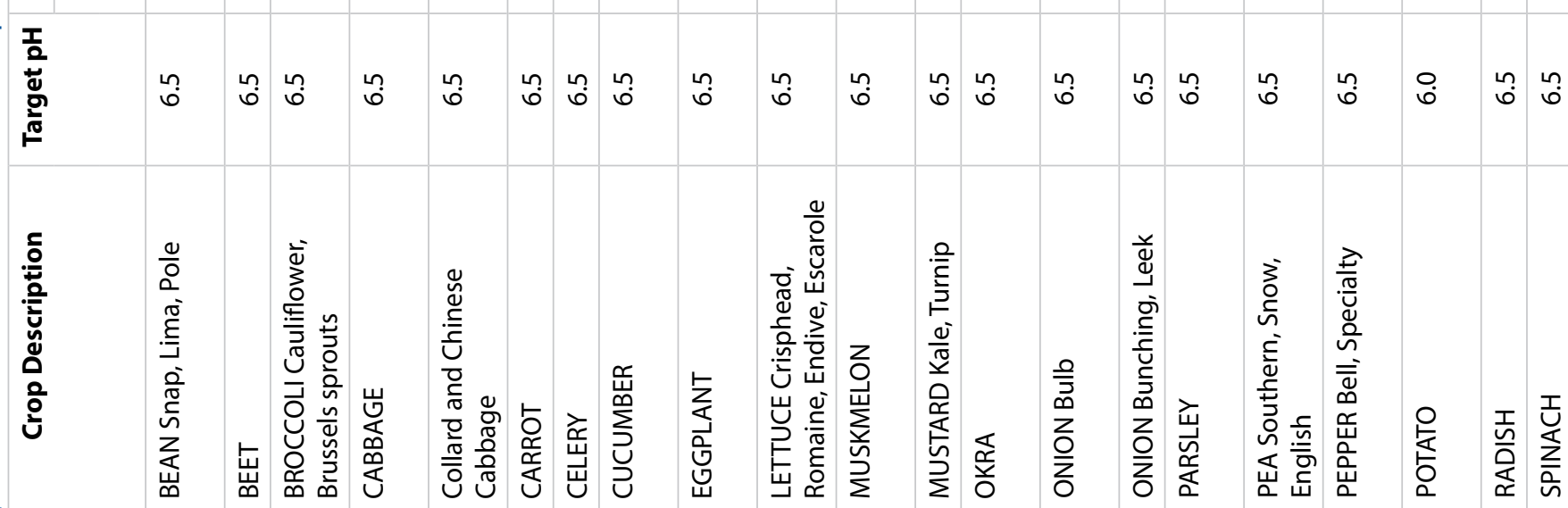




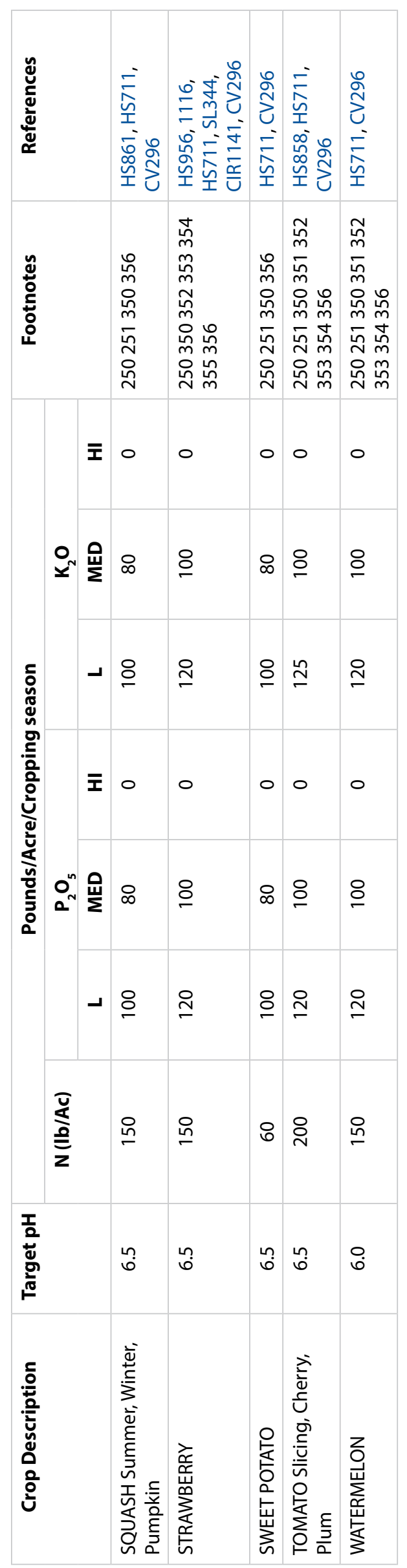


Table 3a. $\mathrm{N}$ recommendation for cabbage grown on bare ground based on plant population (plants per acre), row spacing, and in-row plant spacing. Note: Recommendations for phosphorus $\left(\mathrm{P}_{2} \mathrm{O}_{5}\right)$, potassium $\left(\mathrm{K}_{2} \mathrm{O}\right)$ and magnesium will be based on soil test results for your sample as shown above for cabbage (Table 3).

\begin{tabular}{|l|c|c|c|c|c|c|c|c|}
\hline & \multicolumn{3}{|c|}{ Plant population (plants/acre) as per row spacing (inches) } & \multicolumn{3}{|c|}{ N rate recommended as per row spacing (inches) } \\
\hline $\begin{array}{l}\text { In-row } \\
\text { plant spacing }\end{array}$ & 24 & 30 & 36 & 40 & 24 & 30 & 36 & 40 \\
\hline 8 inches & 32,670 & 26,136 & 21,780 & 19,602 & 376 & 301 & 250 & 225 \\
\hline 10 inches & 26,136 & 20,909 & 17,424 & 15,682 & 301 & 240 & 200 & 180 \\
\hline 12 inches & 21,780 & 17,424 & 14,520 & 13,068 & 250 & 200 & 167 & 150 \\
\hline
\end{tabular}

Table 3b. N recommendation for cabbage grown on plastic mulch based on plant population (plants per acre), bed spacing, number of cultivated rows per bed, and in-row plant spacing. Note: Recommendations for phosphorus $\left(\mathrm{P}_{2} \mathrm{O}_{5}\right)$, potassium $\left(\mathrm{K}_{2} \mathrm{O}\right)$ and magnesium will be based on soil test results for your sample as shown above for cabbage (Table 3).

\begin{tabular}{|l|c|c|c|c|}
\hline & \multicolumn{4}{|c|}{ Plant population (plants/acre) } \\
\hline & $\mathbf{6}$ foot bed spacing (3 foot bed width) & $\mathbf{6 . 6 7}$ foot bed spacing (4 foot bed width) \\
\hline In-row plant spacing & 2 rows & 3 rows & 3 rows & 4 rows \\
\hline 8 inches & 21,780 & 32,670 & 29,403 & 39,204 \\
\hline 10 inches & 17,424 & 26,136 & 23,522 & 31,363 \\
\hline 12 inches & 14,520 & 21,780 & 19,602 & 26,136 \\
\hline 14 inches & 12,446 & 18,669 & 16,802 & \\
\hline & & & & 402 \\
\hline & & $N$ rate recommended (lb/acre) & 361 \\
\hline 10 inches & 250 & 376 & 338 & 301 \\
\hline 12 inches & 200 & 301 & 271 & 258 \\
\hline 14 inches & 167 & 250 & 225 & 193 \\
\hline
\end{tabular}

Table 3c. Recommended N rates for potatoes based on yield goals (cwt/ac). Note: Recommendations for phosphorus $\left(\mathrm{P}_{2} \mathrm{O}_{5}\right)$, potassium $\left(\mathrm{K}_{2} \mathrm{O}\right)$ and magnesium will be based on soil test results of your sample as shown above for potatoes (Table 3).

\begin{tabular}{|c|c|}
\hline Total tuber yield goal (cwt/ac) & Nitrogen rate recommended (lb/ac) \\
\hline 100 & 67 \\
\hline 150 & 100 \\
\hline 200 & 132 \\
\hline 250 & 166 \\
\hline 300 & 197 \\
\hline 350 & 224 \\
\hline 400 & 250 \\
\hline
\end{tabular}


Table 4. Footnotes used with vegetable crops.

$\mathbf{2 5 0}$ Indicated fertilizer amounts, and the nutrients already in the soil, will satisfy the crop nutrient requirement for this cropping season. Fertilizer and water management are linked. Maximum fertilizer efficiency is achieved only with close attention to water management. Supply only enough irrigation water to satisfy crop requirements. Excess irrigation may result in leaching of N and K, creating possible plant deficiencies. Overfertilization has been shown to reduce vegetable quality. For subsurface irrigation, maintain a constant water table between 18 (at planting) and 24 inches (near harvest) below the top of the bed. Monitor water table depth and do not fluctuate, else $\mathrm{N}$ can be "scrubbed" from the root zone. On soils that have not been in vegetable production within the past 2 years, or where micronutrients are known to be deficient, apply $5 \mathrm{lb} \mathrm{Mn}, 3 \mathrm{lb} \mathrm{Zn}, 4 \mathrm{lb} F e, 3 \mathrm{lb} C \mathrm{lu}$, and $1.5 \mathrm{lb}$ B/A. Use soil testing to monitor micronutrient status every 2 years to avoid micronutrient toxicity, because some micronutrients can build up in the soil. When deciding about micronutrient applications, consider micronutrients added to the crop via fungicides. Up to $40 \mathrm{lb} / \mathrm{acre} \mathrm{Mg}$ might be needed when soil test is medium or lower in Mg. Mg can be supplied in fertilizer or from dolomitic limestone, when liming is recommended. Calcium concentrations are typically adequate in most soils used continuously for vegetable production or where the Mehlich-3 Ca index is $>300 \mathrm{ppm}$. Calcium is added during liming activities and from calcium carbonate present in irrigation water drawn from aquifers in Florida. These sources should be considered in the determination of Ca fertilizer needs.

251 For unmulched crops, fertilizer should be applied in split applications to reduce leaching losses and lessen danger of fertilization burn. Broadcast all $\mathrm{P}_{2} \mathrm{O}_{5}$ and micronutrients, if any, and $25 \%$ to $30 \%$ of the $\mathrm{N}$ and $\mathrm{K}_{2} \mathrm{O}$ in the bed at planting. Apply remaining $\mathrm{N}$ and $\mathrm{K}_{2} \mathrm{O}$ in sidedress bands during the early part of the growing season. Additional, supplemental sidedress applications of $30 \mathrm{lb} N / \mathrm{A}$ and $20 \mathrm{lb} \mathrm{K}_{2} \mathrm{O} / \mathrm{A}$ should be applied only if rainfall/irrigation amounts exceed 3 inches within a 3-day period or exceed 4 inches within a 7-day period. Avoid mechanical damage to plants when applying fertilizers.

252 The amounts suggested are generally sufficient for 2 or 3 crops in succession.

253 Where scab-resistant cultivars are grown, a pH between 6.0 and 6.5 is optimum. Where scab-susceptible cultivars are grown, the pH should be below 5.2 or above 7.2. Band all phosphorus. Apply $50 \%$ to $70 \%$ of $\mathrm{N}$ and $50 \%$ of $\mathrm{K}_{2} \mathrm{O}$ at emergence and the remaining $\mathrm{N}$ and $\mathrm{K}$ at 35 to 40 days after planting. Potatoes planted in cool soils might respond to up to $25 \mathrm{lb} \mathrm{P}_{2} \mathrm{O}_{5}$ applied as starter fertilizer in the furrow with the seed pieces.

254 Yield potential for a given area can be assessed by historic total yield (not marketable yield) records considering planting date, previous $\mathrm{N}$-fertilizer application rates and timing, and cultivar.

255 Apply $25 \%-30 \%$ of the $\mathrm{N}$-fertilizer rate required at planting (or near planting), $40 \%-55 \%$ at plant emergence, and $25 \%-30 \%$ at tuber initiation stage. Banding $\mathrm{N}$-fertilizer is recommended.

256 Preplant application of $\mathrm{N}$-fertilizer weeks before planting (e.g., at fumigation) is discouraged because of nitrate leaching risk due to rainfall events.

$\mathbf{3 5 0}$ Supply $25 \%$ to $50 \%$ of the $\mathrm{N}$ in the nitrate form if soils were treated with multipurpose fumigants or if the soil temperature will stay below $60^{\circ} \mathrm{F}$ for up to one week following transplanting or germination.

351 For mulched crops and subsurface irrigation, incorporate $10 \%$ to $20 \%$ of the $\mathrm{N}_{\text {and }} \mathrm{K}_{2} \mathrm{O}$, plus all of the $\mathrm{P}_{2} \mathrm{O}_{5}$ and micronutrients, if any, into the bed. Apply the remainder of the $\mathrm{N}$ and $\mathrm{K}_{2} \mathrm{O} 2$ to 3 inches deep in one or more bands about 6 to 10 inches from the plants. For drip irrigation, incorporate $20 \%$ to $40 \%$ of the $\mathrm{N}$ and $\mathrm{K}_{2} \mathrm{O}$ and all of the $\mathrm{P}_{2} \mathrm{O}_{5}$ and micronutrients, if any, into the bed. Apply the remainder of the $\mathrm{N}$ and $\mathrm{K}_{2} \mathrm{O}$ periodically through drip tubes according to the rate or crop growth. Consult AE259, "Scheduling Tips For Drip Irrigation of Vegetables," AE260," Principles and Practices of Irrigation Management for Vegetables," and AE500, "How to Determine Run Time and Irrigation Cycles for Drip Irrigation: Tomato and Pepper Examples " for information on injection schedules. For management systems where both subsurface and drip irrigation are being used, apply no more than $20 \%$ of the $\mathrm{N}_{\text {and }} \mathrm{K}_{2} \mathrm{O}$, plus all of the $\mathrm{P}_{2} \mathrm{O}_{5}$ and micronutrients, if any, into the bed. Apply the remainder of the $\mathrm{N}$ and $\mathrm{K}_{2} \mathrm{O}$ periodically through drip tubes according to the rate of crop growth. For overhead irrigation, incorporate all of the $\mathrm{N}, \mathrm{P}_{2} \mathrm{O}_{5}, \mathrm{~K}_{2} \mathrm{O}$ and micronutrients, if any, into the bed prior to installation of the plastic mulch.

352 Amounts suggested are for the first crop. Squash and cucumber following other crops on the same mulch may not need substantial additional fertilizer. If fertilizer is needed for the second crop, apply fertilizer using a liquid-injection wheel or via drip irrigation. Apply no more than 30 to $40 \mathrm{lb} / \mathrm{acre} \mathrm{N}$ and/or $\mathrm{K}_{2} \mathrm{O}$ in any single injection wheel application.

353 From 25 to $30 \%$ of the $\mathrm{N}$ may be supplied from slow-release $\mathrm{N}$ sources, such as sulfur-coated urea, polymer-coated fertilizers, or isobutylidene-diurea (IBDU).

354 Transplants may benefit from application of a dilute, soluble starter fertilizer, especially at cool soil temperatures. Starter solution rates of $\mathrm{N}$ and $\mathrm{P}_{2} \mathrm{O}_{5}$ need not exceed 10 to $15 \mathrm{lb} /$ acre each.

355 For overhead irrigation, broadcast all the $\mathrm{P}_{2} \mathrm{O}_{5}$ and micronutrients, if any, and $25 \%$ of the $\mathrm{N}$ and $\mathrm{K}_{2} \mathrm{O}$ into the bed. Band remaining $\mathrm{N}$ and $\mathrm{K}_{2} \mathrm{O}$ in center of bed 3 inches deep. For subsurface irrigation, incorporate $10 \%$ to $20 \%$ of the $\mathrm{N}_{\text {and }} \mathrm{K}_{2} \mathrm{O}$, plus all of the $\mathrm{P}_{2} \mathrm{O}_{5}$ and micronutrients, if any, into the bed. Apply the remainder of the $\mathrm{N}_{\text {and }} \mathrm{K}_{2} \mathrm{O} 2$ to 3 inches deep in one or more bands about 6 to 10 inches from the plants. For drip irrigation, incorporate $20 \%$ of the $\mathrm{N}$ and $\mathrm{K}_{2} \mathrm{O}$ and all of the $\mathrm{P}_{2} \mathrm{O}_{5}$ and micronutrients, if any, into the bed. Apply the remainder of the $\mathrm{N}$ and $\mathrm{K}_{2} \mathrm{O}$ periodically through drip tubes according to the rate of crop growth; see AE354, "Automatic Irrigation Based on Soil Moisture for Vegetable Crops," AE500, " How to Determine Run Time and Irrigation Cycles for Drip Irrigation: Tomato and Pepper Examples," AE260, " Principles and Practices of Irrigation Management for Vegetables," and Circular 1141, " Fertilization of Strawberries in Florida ." For management systems where both subsurface and drip irrigation are being used, apply no more than $20 \%$ of the $\mathrm{N}$ and $\mathrm{K}_{2} \mathrm{O}$, plus all of the $\mathrm{P}_{2} \mathrm{O}_{5}$ and micronutrients, if any, into the bed. Apply the remainder of the $\mathrm{N}_{\text {and }} \mathrm{K}_{2} \mathrm{O}$ periodically through drip tubes according to the rate of crop growth. 
356 UF/IFAS fertilization and liming recommendations are advisory in nature and emphasize efficient fertilizer use and environmentally sound nutrient management without losses of yield or crop quality. It is generally assumed the nutrients will be supplied from purchased commercial fertilizer and the expected crop yields and quality will be typical of economically viable production. Growers should consider UF/IFAS recommendations in the context of their entire management strategy, such as return on investment in fertilizer and the benefits of applying manure or biosolids (sewage sludge) to their land. There is insufficient research available to support the use of UF/IFAS soil test results for environmental nutrient management purposes. Such use is discouraged until correlation is proven.

Table 5. Typical bed (row) spacings for vegetables.

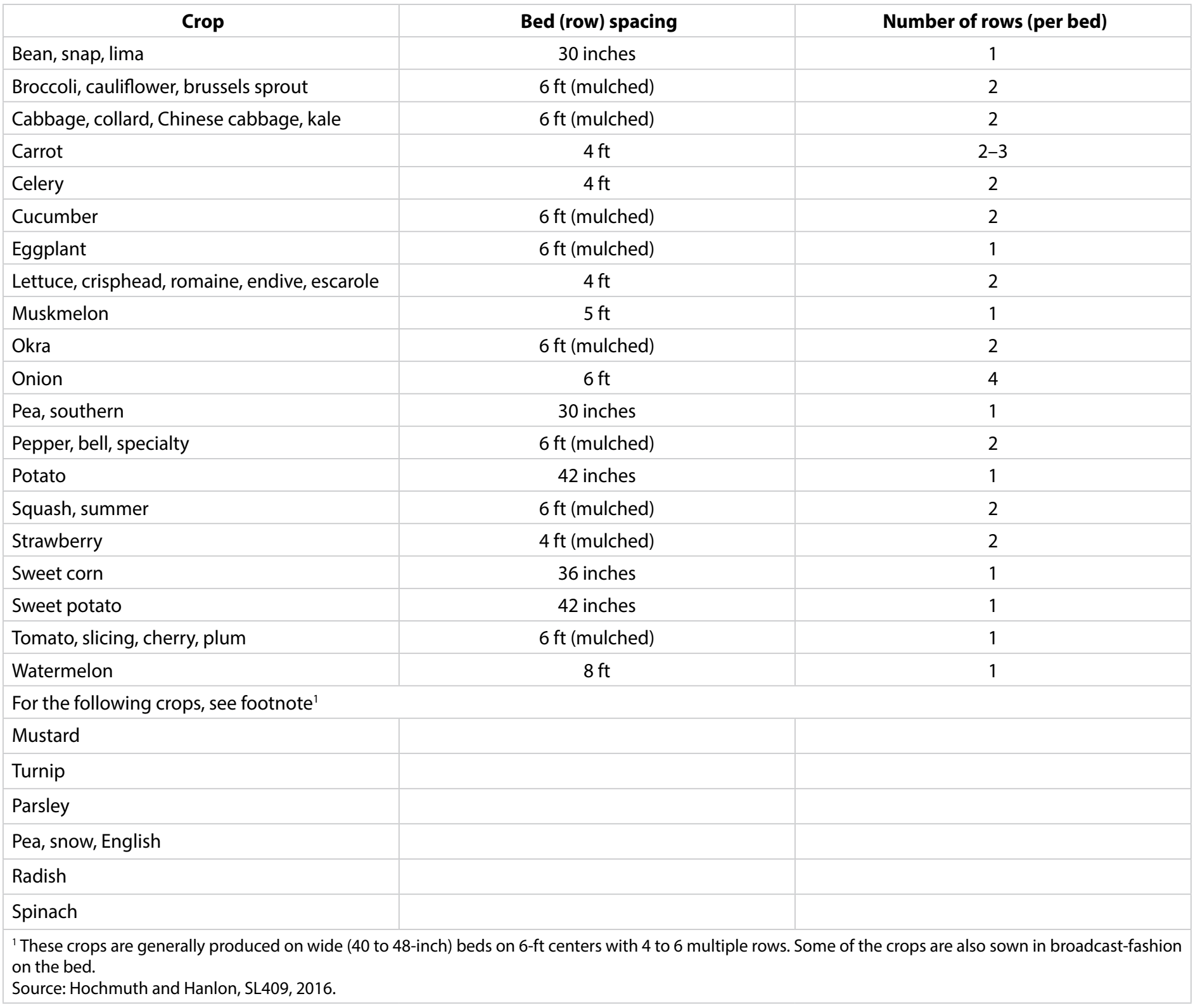


Table 6. Conversion of fertilizer rates in lb/A to lb/100 linear bed ft (LBF)'

\begin{tabular}{|c|c|c|c|c|c|c|c|c|c|c|c|c|c|}
\hline \multirow[t]{3}{*}{ Bed spacing (ft) } & \multicolumn{13}{|c|}{ Recommended fertilizer $\left(\mathrm{N}, \mathrm{P}_{2} \mathrm{O}_{5}\right.$, or $\left.\mathrm{K}_{2} \mathrm{O}\right)$} \\
\hline & \multicolumn{13}{|c|}{ 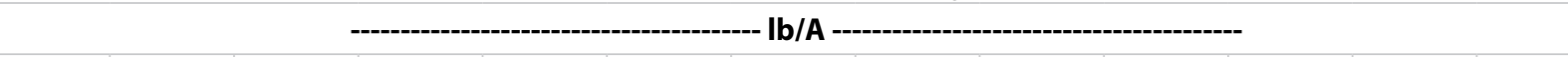 } \\
\hline & 20 & 25 & 40 & 50 & 60 & 75 & 80 & 100 & 120 & 140 & 160 & 180 & 200 \\
\hline & \multicolumn{13}{|c|}{ Pounds of fertilizer $\left(\mathrm{N}, \mathrm{P}_{2} \mathrm{O}_{5}\right.$, or $\left.\mathrm{K}_{2} \mathrm{O}\right)$ to apply per $100 \mathrm{LBF}$} \\
\hline 3 & 0.14 & 0.17 & 0.28 & 0.35 & 0.41 & 0.52 & 0.55 & 0.69 & 0.83 & 0.96 & 1.10 & 1.24 & 1.38 \\
\hline 4 & 0.18 & 0.23 & 0.37 & 0.46 & 0.55 & 0.69 & 0.73 & 0.92 & 1.10 & 1.29 & 1.47 & 1.65 & 1.84 \\
\hline 5 & 0.23 & 0.29 & 0.46 & 0.57 & 0.69 & 0.86 & 0.92 & 1.15 & 1.38 & 1.61 & 1.84 & 2.07 & 2.30 \\
\hline 6 & 0.28 & 0.34 & 0.55 & 0.69 & 0.83 & 1.03 & 1.10 & 1.38 & 1.65 & 1.93 & 2.20 & 2.48 & 2.77 \\
\hline 8 & 0.37 & 0.46 & 0.73 & 0.92 & 1.10 & 1.38 & 1.47 & 1.84 & 2.20 & 2.57 & 2.94 & 3.31 & 3.67 \\
\hline \multicolumn{14}{|c|}{$\begin{array}{l}{ }^{1} \text { This table is used correctly by (1) determining the typical bed spacing from Table } 5 \text { for the crop; ( } 2 \text { locating the column containing the recommended fertilizer } \\
\text { rate in pounds per acre; and ( } 3 \text { ) reading down the column until reaching the row containing the typical bed spacing. The resulting number in pounds per } 100 \\
\text { LBF should be used even in situations where the farmer's bed spacing differs from the typical bed spacing. Use of the table will involve doubling the rate, for } \\
\text { example where the column for } 100 \text { pounds per acre was used in the calculation of pounds per } 100 \mathrm{LBF} \text { for a recommended rate of } 200 \text { pounds per acre. } \\
\text { Source: Hochmuth and Hanlon, SL409, } 2016 \text {. }\end{array}$} \\
\hline
\end{tabular}

